\title{
Discussion: Measuring the plastic limit of fine soils: an experimental study
}

Vinayagamoorthy Sivakumar MSc, PhD, DIC, DSc, CEng, FICE Reader, School of Planning, Architecture and Civil Engineering, Queen's University Belfast, UK

Brendan C. O'Kelly PhD, FTCS, CEng, CEnv, MICE

Associate Professor, Department of Civil, Structural and Environmental Engineering, Trinity College Dublin, Dublin, Ireland

Laura Henderson PhD

Research Engineer, Norwegian Geotechnical Institute, Oslo, Norway
Catherine Moorhead MEng, PhD

Teaching Assistant, Queen's University Belfast, Belfast, UK

Shiao Huey Chow PhD

Assistant Professor, University of Western Australia, Perth, Australia

Graham Edward Barnes MSc, PhD, CEng, FICE, CGeol, FGS

Consultant, Manchester, UK

\section{Contribution by G. E. Barnes}

The authors have presented an interesting study (Sivakumar et al., 2015) of fall cone devices on soils near the plastic limit. For decades researchers have investigated cone devices in an attempt to find a more reliable and repeatable method of obtaining the plastic limit. Currently, there is only one internationally recognised, standard test for the plastic limit, namely the manual thread-rolling method.

The discusser was astonished to see the standard plastic limit described as 'Casagrande PL' (also 'Casagrande LL', but this would have to be the cup, not cone, method) as these limits have always been attributed to Atterberg (1911) and recognised as 'Atterberg limits' for over a century (Kinnison, 1915).

The authors observe that plastic limit is the water content at the transition between plastic and semi-solid states, the ductile-brittle transition (Barnes, 2009, 2013a, 2013b), and they acknowledge that different mechanisms occur in the cone and thread-rolling tests. Wood (1983: p. 80) observed, 'It is not clear how the cone penetrometer plastic limit gives an indication of the water content at which a soil changes from the brittle to the plastic state.' It is difficult to see how a cone device can be expected to replace the thread-rolling method which, irrespective of its limitations and with the authors' acknowledgement, identifies this transition.

The 'new limit', $\mathrm{PL}_{(100)}$ (Harison, 1988), is imprecise for the following reasons.

(a) The term 'plastic' (P) should not be used, as the water content of a soil at $100 \times c_{\mathrm{u}(\mathrm{LL})}$ could be less than the standard plastic limit, in the brittle state.

(b) The term 'limit' (L) should not be used as $\mathrm{PL}_{(100)}$ does not define a limit between one state and another state. Figure 7 does not display any indication of a change of state. (c) The subscript (100) must assume a unique $c_{\mathrm{u}(\mathrm{LL})}$. Use of this subscript requires a standardised, internationally agreed $c_{\mathrm{u}(\mathrm{LL})}$. The authors report $c_{\mathrm{u}(\mathrm{LL})}=1.7 \mathrm{kPa}$, but recognise its inaccurate measurement. It is known to vary significantly - for example, Skempton and Northey (1953) $0 \cdot 7-1 \cdot 5 \mathrm{kPa}$, Wasti and Bezirci (1986) $0 \cdot 5-5 \cdot 6 \mathrm{kPa}$ and Kayabali and Tufenkci (2010) $1 \cdot 2-12 \cdot 0 \mathrm{kPa}$

The wide variation of strength at the plastic limit is also well known and should not need repeating.

The authors conclude that their set-up provides 'PLs (presumably $\left.\mathrm{PL}_{(100)} \mathrm{s}\right)$ in good agreement with the measured Casagrande PLs', although it is not justified to corroborate the standard PL with the cone PL. Because of the inherent (human) variability of standard PLs (see Figure 12), comparison with PLs from cone devices should not be expected always to display close correlation.

The authors are clear that $\mathrm{PL}_{(100)}$ does not have to correspond to the brittle transition and that $\mathrm{PL}_{(100)}$ should not be expected to align with the standard PL. To include $\mathrm{PL}_{(100)}$ alongside the standard PL will provide confusion with little extra benefit. $\mathrm{PL}_{(100)}$ cannot be used in the multitude of trusted correlations (mainly with plasticity index) that have developed over many years.

It would help if the authors made clear whether their aim is to produce an apparatus to determine $\mathrm{PL}_{(100)}$, or a new device to replace the standard method.

\section{Authors' reply}

The authors wish to thank the discusser for the interest shown in their paper and for drawing attention to some important 


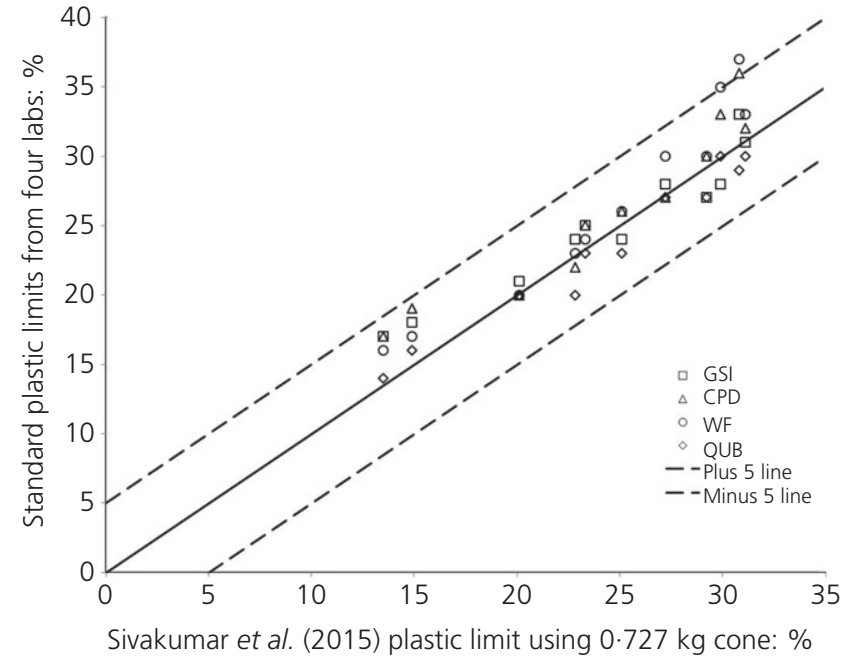

Figure 12. Standard plastic limits compared with the $\mathrm{PL}_{(100)}$ of Sivakumar et al. (2015) (GSI: Glover Site Investigation Ltd; CPD: Central Procumbent Division, Nl; WF: Whiteford Geoservices; QUB: Queen's University Belfast)

and fundamental issues regarding the quantity termed the 'plastic strength limit', $\mathrm{PL}_{100}$.

The $\mathrm{PL}_{100}$ has been defined and described in many publications as the water content corresponding to a 100-fold increase in the liquid limit (LL) undrained strength (see Haigh et al. (2013), Kyambadde and Stone (2012), Kyambadde et al. (2014), O'Kelly (2013), Stone and Kyambadde (2007), Stone and Phan (1995), to name a few). In the authors' study, the liquid limit was determined using the British Standard method (BSI, 1990), with this standard fall-cone liquid limit $\left(\mathrm{LL}_{\mathrm{FC}}\right)$ corresponding to a (dynamic) undrained strength of $2.66 \mathrm{kPa}$ (Koumoto and Houlsby, 2001).

The paper is unambiguous in that the presented new $0.727 \mathrm{~kg}$ $200 \mathrm{~mm}$ fall cone set-up, which uses an energy-based approach, measures the $\mathrm{PL}_{100}$, which is fundamentally different from the conventional plastic limit (PL) defined through the threadrolling test. The latter defines the transition between the plastic and semi-solid states (onset of brittleness) and does not correspond to a fixed value of soil strength. Hence the strength ratio over the range of water contents for which a soil behaves plastically is not always a factor of 100 , but can vary over a large range (Barnes and O'Kelly, 2011; Haigh et al., 2013; O'Kelly, 2013; to name a few). In other words, the PL values obtained for the same soil by these two very different methodologies ( $\mathrm{PL}_{100}$ and thread-rolling $\mathrm{PL}$ ) should not be expected to have more than a coincidental equivalence (Feng, 2000; Haigh et al., 2013; Kodikara et al., 2006; Leroueil and Le Bihan, 1996; O'Kelly, 2013, 2014; to name a few). The above facts have been repeatedly emphasised in the paper under discussion. In closing the discussion section of the paper, the authors state that 'Any argument is not scientifically justified to corroborate PL measurements determined using the new method with those obtained using the classical [PL] approach.'

The discusser mentions that the $\mathrm{PL}_{100}$ should not be used in the multitude of trusted correlations (mainly with plasticity index, PI) that have developed over many years. However, as described by Haigh et al. (2013) and Kyambadde et al. (2014), for correlations with strength and stiffness, the $\mathrm{PL}_{100}$ or the plasticity index $\mathrm{PI}_{100}$ (Equation 4) would be the favourable choice since they are implicitly linked to the strength variation with water content.

$$
\text { 4. } \mathrm{PI}_{100}=\mathrm{LL}_{\mathrm{FC}}-\mathrm{PL}_{100}
$$

Again, it is emphasised that this approach should be considered as providing additional index parameters that are fundamentally different from the plastic limit and plasticity index computed from the LL and PL values determined using the percussion cup and thread-rolling methods. If the brittle transition point is required, then a thread-rolling test in keeping with the essence of Atterberg, Terzaghi and Casagrande is recommended.

Using data from Table 1 in the paper, the discusser has produced Figure 12; this highlights the inherent variability of the PLs determined by the thread-rolling method. Data from the same table were used in producing Figure 8 in the paper, but the authors plotted the average of the four thread-rolling PLs determined for each of the 11 soils tested by the different laboratories. Notwithstanding that the strength ratio over the plastic range is not always a factor of 100, Figure 8 indicates that for the 11 different soils examined (ranging from intermediate to very high plasticity), good overall agreement was found between the experimental $\mathrm{PL}_{100}$ values derived using the $0.727 \mathrm{~kg}-200 \mathrm{~mm}$ fall cone set-up and the average of the four thread-rolling PLs.

Figure 12 is a good demonstration of the possible variation (by up to $12 \%$ (Sherwood, 1970)) that can be expected in the water content determined for the PL by the thread-rolling method, with a maximum variation of $8 \%$ found between the four PLs measured for a given soil in the authors' study. Vardanega and Haigh (2014) have pointed out that the systematic bias in water content at the thread-rolling PL arising due to operator sensitivity can have a significant effect on the calculation of the liquidity index, particularly for soils having low plasticity index close to the PL. This bias associated with the thread-rolling PL could be argued as another reason for favouring the $\mathrm{PL}_{100}$ when dealing with strength and stiffness correlations, as reported by Haigh et al. (2013) and 
Kyambadde et al. (2014). In conclusion, the authors thank the discusser for the opportunity to further elaborate on these fundamental points to their energy-based fall cone set-up for the determination of the plastic strength limit $\mathrm{PL}_{100}$.

\section{REFERENCES}

Atterberg A (1911) Uber die physikalische Bodenuntersuchung und uber die Plastizitat der tone. (On the physical testing of soil and the plasticity of clays) Internationale Mitteilungen fur Bodenkunde 1(1): 10-43 (in German).

Barnes GE (2009) An apparatus for the plastic limit and workability of soils. Proceedings of the Institution of Civil Engineers - Geotechnical Engineering 162(3): 175-185, http://dx.doi.org/10.1680/geng.2009.162.3.175.

Barnes GE (2013a) The Plastic Limit and Workability of Soils. $\mathrm{PhD}$ thesis, University of Manchester, Manchester, UK.

Barnes GE (2013b) An apparatus for the determination of the workability and plastic limit of clays. Applied Clay Science 80-81: 281-290.

Barnes GE and O'Kelly BC (2011) Discussion: An apparatus for the plastic limit and workability of soils. Proceedings of the Institution of Civil Engineers - Geotechnical Engineering 164(4): 293-294, http://dx.doi.org/10.1680/geng.2011. 164.4.293.

BSI (1990) BS 1377-2: Methods of test for soils for civil engineering purposes - Part 2: Classification tests. BSI, London, UK.

Feng TW (2000) Fall cone penetration and water content relationship of clays. Géotechnique 50(2): 181-187.

Haigh SK, Vardanega PJ and Bolton MD (2013) The plastic limit of clays. Géotechnique 63(6): 435-440.

Harison JA (1988) Using the BS cone penetrometer for the determination of the plastic limit of soils. Géotechnique 38(3): 433-438.

Kayabali K and Tufenkci oo (2010) Shear strength of remolded soils at consistency limits. Canadian Geotechnical Journal 47: 259-266.

Kinnison CS (1915) A Study of the Atterberg Plasticity Method. Bureau of Standards, Department of Commerce, Washington, DC, USA, Technical Paper No. 46.

Kodikara JK, Seneviratne HN and Wijekulasuriya CV (2006) Discussion on 'Using a small ring and fall-cone to determine the plastic limit'. Geotechnical and Geoenvironmental Engineering 132(2): 276-278.
Koumoto T and Houlsby GT (2001) Theory and practice of the fall cone test. Géotechnique 51(8): 701-712.

Kyambadde BS and Stone KJL (2012) Index and strength properties of clay-gravel mixtures. Proceedings of the Institution of Civil Engineers - Geotechnical Engineering 165(1): 13-21, http://dx.doi.org/10.1680/geng. 2012.165.1.13.

Kyambadde BS, Stone KJL and Barnes GE (2014) Discussion: Index and strength properties of clay-gravel mixtures. Proceedings of the Institution of Civil Engineers Geotechnical Engineering 167(1): 83-86, http://dx.doi.org/ 10.1680/geng.12.00116.

Leroueil S and Le Bihan JP (1996) Liquid limits and fall cones. Canadian Geotechnical Journal 33(5): 793-798.

O'Kelly BC (2013) Atterberg limits and remolded shear strength-water content relationships. Geotechnical Testing Journal 36(6): 939-947.

O'Kelly BC (2014) Closure to discussion by K Prakash and A Sridharan on Atterberg limits and remolded shear strength-water content relationships. Geotechnical Testing Journal 37(4): 729-731.

Sherwood PT (1970) The Reproducibility of the Results of Soil Classification and Compaction Tests. Road Research Laboratory, Crowthorne, UK, Report LR 339.

Sivakumar V, O'Kelly BC, Henderson L, Moorhead C and Chow SH (2015) Measuring the plastic limit of fine soils: an experimental study. Proceedings of the Institution of Civil Engineers - Geotechnical Engineering 168(1): 53-64, http:/l dx.doi.org/10.1680/geng.14.00004.

Skempton AW and Northey RD (1953) The sensitivity of clays. Géotechnique 3(1): 30-53.

Stone KJL and Kyambadde BS (2007) Determination of strength and index properties of fine-grained soils using a soil minipenetrometer. Geotechnical and Geoenvironmental Engineering 133(6): 667-673.

Stone KJL and Phan CD (1995) Cone penetration tests near the plastic limit. Géotechnique 45(1): 155-158.

Vardanega PJ and Haigh SK (2014) The undrained strengthliquidity index relationship. Canadian Geotechnical Journal 51(9): 1073-1086.

Wasti Y and Bezirci MH (1986) Determination of the consistency limits of soils by the fall cone test. Canadian Geotechnical Journal 23(2): 241-246.

Wood DM (1983) Discussion on cone penetrometer and liquid limit. Géotechnique 33(1): 76-80. 